\title{
HOW MIGHT CLIMATE CHANGE AFFECT MICROECONOMIC WELLBEING IN CENTRAL ASIA
}

\author{
Umar Burkhanov, ${ }^{1}$ Feruza Saburova ${ }^{2}$
}

\begin{abstract}
Climate change may pose serious challenges to the economies of Central Asian countries, but in-depth studies on a national level are lacking. The paper is aimed to contribute filling this gap and devoted to assessing the economic impacts of climate change in selected areas of Central Asia. The methods of the desk study and documental analysis are used to summarize the adverse effects of climate change in rural livelihoods. Moreover, the preliminary results of the survey conducted in selected regions of Fergana valley within MikroKlima project used as a corresponding data for economic impact analysis on a household level. The results reveal that the effects of unfavorable weather conditions uneven for short and long term, and across Central Asia. Moreover, the most potential damage from climate change will affect the rural population, and there is also a high positive correlation between water shortage, increased aridity, and poverty, aggravated by climate change.
\end{abstract}

JEL Classification numbers: Q51, Q54, O11, O18; DOI: http://dx.doi.org/10.12955/cbup.v5.905

Keywords: climate change, household, income, agriculture, water, Central Asia, Uzbekistan.

\section{Introduction}

Central Asia (CA) is a sub-region of Asia. The sub-region covers about 400 million sqr km which constitute of the five former Soviet republics: Kazakhstan, Kyrgyzstan, Turkmenistan, Tajikistan, and Uzbekistan. The total population of people living in the region by the end of 2013 was 67.4 million of which 58\% lived in the rural areas (Sommer, Glazirina \& Yuldashev, 2012). The new World Bank classification placed the five Soviet republics among the countries with uneven income levels. The World Bank went ahead to classify Kazakhstan and Turkmenistan in the upper-middle-income countries and Uzbekistan, Kyrgyzstan and Tajikistan in the lower middle-income countries.

Kazakhstan and Turkmenistan are rich in oil, and they do not rely much on agriculture. However, the other three countries rely on agricultural production as their primary source of household income (Bobojonov \& Aw-Hasan, 2014). The agriculture sector in these countries generates export revenues which are used in the development of their economies. However, these countries face complex environmental challenges, in particular in the areas of food security, healthcare, access to water and energy which made them be the most vulnerable regions in the world (Bucknall et al., 2003; Glantz, 2005). The table below is a summary of the economic statistics of the five CA countries in the focus of biodiversity.

Table 1: Economic statistics of countries in the focus of biodiversity

\begin{tabular}{|l|l|l|l|l|l|}
\hline Country & $\begin{array}{l}\text { Population by } \\
\text { income group }\end{array}$ & $\begin{array}{l}\text { GDP per } \\
\text { capita (for } \\
2016)\end{array}$ & $\begin{array}{l}\text { GDP } \\
\text { growth } \\
\text { annual\%, } \\
2015)\end{array}$ & $\begin{array}{l}\text { The net volume of } \\
\text { official } \\
\text { development } \\
\text { assistance } \\
\text { received (2014, } \\
\text { million dollars) }\end{array}$ & $\begin{array}{l}\text { Ther } \\
\text { amount of } \\
\text { ODA } \\
\text { received in\% } \\
\text { of GNI (2014) }\end{array}$ \\
\hline Kazakhstan & Upper middle & $\$ 25669$ & 1.2 & 88.4 & 0.0 \\
\hline Kyrgyzstan & Lower middle & $\$ 3467$ & 3.5 & 624.1 & 8.6 \\
\hline Tajikistan & Lower middle & $\$ 2982$ & 6.0 & 356.3 & 3.1 \\
\hline Turkmenistan & Above average & $\$ 17347$ & 6.5 & 34.2 & 0.1 \\
\hline Uzbekistan & Upper middle & $\$ 6453$ & 8 & 324.4 & 0.5 \\
\hline Source. Ndamani \& Watanabe (2017).
\end{tabular}

Moreover, the study that was done by Bobojonov \& Aw-Hassan (2014) showed a significant uncertainty about the effects of Climatic Change (CC) in Asia sub-regions such as CA. Thus, a

\footnotetext{
${ }^{1}$ Lecturer at Tashkent Financial Institute, Uzbekistan, uburkhan@ gmail.com

${ }^{2}$ Master's program student, Tashkent Financial Institute, Uzbekistan, ewulet93@mail.ru
} 
detailed bio-economic characterization of the impacts of $\mathrm{CC}$ on households in $\mathrm{CA}$ is outstanding. However, there is a need for deeper $\mathrm{CC}$ related research at the country level. The paper is aimed to contribute to the filling research gap and devoted to assessing the impacts of $\mathrm{CC}$ on household wellbeing in CA.

\section{Literature Review}

The study uses the outcomes of different international projects including, "The Env-Linkages Economic baseline projections to 2050"(2011), "Zoi Environment Network project" (2016), Solomon, (2007), "The World Banks" (2009). Most of the scholarly studies reviewed during the research focused on water system management, agriculture and food security (Bezborodov et al., 2010; Siegfried et al., 2012; Sommer et al., 2012; Tirado et al., 2010; Ndamani \& Watanabe, 2017; Bobojonov \& Aw-Hassan, 2014).

Other studies devoted to the issues of health, adaptation, economics and environment particularly the economic growth, green tax and intergenerational environment cost burden sharing (Bernard, et. al., 2015, Bell et al., 2007; Dessai 2003; Fay et al., 2010; Flaherty, et al., 2016; Lecocq \& Shalizi, 2007).

The economic impacts of CC in many cases address on global scale effects are discussed by (Stern 2007; Fay et al., 2010; Metz 2007) and some predictions of these studies have been given in Appendix A. However, in recent years, economic impacts analysis on national level has emerged to demonstrate the value of country and city scale works. Despite the proliferation of research on different areas, the assessment of the economic impacts of $\mathrm{CC}$ at the national level has received little attention.

\section{Methodology and data source}

The methods of the desk study and documental analysis are used to summarize the adverse effects of climate change in rural livelihoods in CA. The research uses the results of the Integrated Model to assess the impact of $\mathrm{CC}$ on the main crops which have crucial importance for the households in $\mathrm{CA}$ (Bobojonov \& Aw-Hassan, 2014). Further, the outcomes of simulation models based on Metz (2007) CC scenario projections, and the results of different modeling approaches, including a Bio-Economic model to assess the effects of $\mathrm{CC}$ on food production, Biophysical models at various crops using SOYGRO, CERES, DSSAT modeling are also employed in this study.

The research uses some of the results of the survey conducted by Bobojonov \& Aw-Hassan (2014) among 97 respondents living in Osh oblast, Kyrgyzstan as the primary source of data on a household level.

\section{Findings and discussion}

The environmental changes add to the problems in the CA and increase the vulnerability of people living in rural areas. Notably, the recent increase in the frequency of droughts is resulting in severe damage to the livelihoods of farmers in semiarid and arid regions. For instance, the poorest population living in mountainous areas of CA droughts in 2000-2001 and 2007-2008 have caused significant socio-economic is hitting the hardest because of increased frequency of heavier rainfalls in winter and subsequent floods.

Rural populations are already severely suffering from the increasing sequence of extreme events, which will predict even to increase in future. The study by Metz (2007) indicates that the region may face declined precipitation during spring, summer, and autumn and slightly increased rainfall during the winter (Solomon, 2007). Further, the rise of temperature by $3.7^{\circ} \mathrm{C}$ can occur on average by the end of this century. The followed extreme weather expected to occur during summer, which is the most important season in the vegetation period. The increased temperatures may cause a higher probability of drought during the vegetation period which may lead declining harvest in agriculture (Metz, 2007).

Table 2 shows the significant role agriculture plays in household income in CA countries with employment in the agricultural sector as over $25 \%$ in all CA countries. For instance, in Tajikistan, two-thirds of the population depends on agriculture for their livelihood, whereas in Kyrgyzstan more than half of labor force employed in agriculture sectors.

Within MikroKlima project we surveyed the importance of agriculture in household income, in October 2016. The household sources of revenue were ranked in the order of importance: wage, remittances from abroad, and sales of primary agricultural products (sales of farm products from the household plot account for $20 \%$ of family earnings). These findings are consistent with the earlier 
(FAO, 2014) studies which indicated that even small farmers don't wholly rely on agricultural produce. Although only 4 out of 97 respondents showed the sale of agricultural commodities as the primary source of income source, their earnings mostly come from sales of both plants and animal produce. Most of the plant output sale seasonally. Among the livestock production, animals and meat are mostly sold seasonally and even less rare than that, whereas dairy and eggs sale daily and weekly.

Table 2: Importance of Agriculture in CA (Employment and GDP)

\begin{tabular}{|l|l|l|l|}
\hline Countries & $\begin{array}{l}\text { Employment in } \\
\text { Agriculture }\end{array}$ & $\begin{array}{l}\text { Agriculture as \% of } \\
\text { GDP }\end{array}$ & Major Exports (agriculture) \\
\hline Kazakhstan & $<10 \%$ & $<10 \%$ & Grains \\
\hline Kyrgyzstan & $55 \%$ & $35 \%$ & Cotton, Horticulture \\
\hline Tajikistan & n/a & $25 \%$ & Cotton \\
\hline Turkmenistan & n/a & $30 \%$ & Cotton \\
\hline Uzbekistan & $40^{3} \%$ & $20 \%$ & Cotton, grain \\
\hline Source: Granit et al., 2010. &
\end{tabular}

The study of the role of agriculture also reveals the dominance of cotton production in the sector. For instance, Uzbekistan is currently the second largest exporter of cotton in the world, selling over 800,000 metric tons every year (Bernauer \& Siegfried, 2012).

The results of existing studies show the adverse effects of $\mathrm{CC}$ on the livelihoods of small farmers and households who are currently operating at a small margin of profits. Survey reveals that unexpected freezing in 2016 has impeded timely harvest of beats and ripening of tomatoes in Osh oblast. Such loss hits the revenue basket of the producers, as they only have a seasonal chance to obtain income. Furthermore, the vulnerability of animal farming to CC lies in the perceptivity of animals to diseases with increasing temperatures and lack of drinking water with increasing aridity. Moreover, do not have access to financial resources and advanced technologies in the region raises the vulnerability of them.

The data for Europe and CA demonstrate substantiality of the economic impact of CC over the past 30 years; climate-related disasters have caused $\$ 70$ billion in economic losses (Glantz, 2005). The existing studies at national or sub-national levels of the economic impacts of $\mathrm{CC}$ on agricultural production in CA are limited ${ }^{4}$.

Water Resources \& Irrigation system

CA already meets notable warnings from weather change, with some serious risks already in evidence. Today, traditionally critical sectors of economies in CA the water and agriculture became the most vulnerable area to CC (Solomon, 2007).

The value of water and agriculture hard to overestimate for the region. Those two sectors are acknowledged together since in the CA they are firmly interlinked - more than $90 \%$ of water in the area goes to irrigated farming. For instance, the results of a survey conducted in Osh oblast reveal that 90 respondents out of 97 irrigated at least a small chunk of their land, which means that the rest (only seven respondents) do not use any irrigation.

According to Glantz (2005), the agriculture sector contributes about $30 \%$ of the CAs GDP and hires more than $60 \%$ of the population. The studies of potential adverse effects from the unfavorable weather conditions evidence that suffer from such a changes will be more than $70 \%$ for the agriculture sector. One of the cases on how aridity, caused by weather change, may affect people's living, is the dryness of 2008 in Tajikistan (Anisimov \& Ginsburg, 2008). Because of it, many families lost a considerable part of the wheat crop and had to sell their cattle as the grain harvest totals were short by $30-40 \%$ through the whole year.

\footnotetext{
${ }^{3}$ According to data from Statistic Committee of Uzbekistan this indicator was 27\% in 2016.

${ }^{4}$ One of the first few assessments was done by Savoskul et al. (2004) for the Syr Darya river basin.
} 
The studies reveal that the lack of fresh water may become the acutest problem in CA. According to Metz's (2007) forecast, in western and southern regions of CA, where the farming facilities established, and the substantial amount of the people lives, the decline of yearly runoff may reach by $10-20 \%$.

The situation aggravated by increasing unevenness of flow effected by the disappearance of icecaps as stream accumulators; consequently, seasonal floods expected to become more rapid and significant water shortage in the summertime. It seems contradictory as the global medium precipitation volume persists approximately the same level; the rainfall frequency is shifting more uneven regarding time and area.

In Uzbekistan, Amu-Darya basin covers $81.5 \%$ of the country's need for water, and Syr-Darya basin includes $13.5 \%$ (Dukhovny \& Sokolov, 2003). There are many irrigation constructions along the two rivers. These irrigation schemes significantly reduce the volume of run-off in both rivers and thus the inflow into the Aral Sea.

The research reveals that in the past century, Tajikistan's icecaps have lost more than $20 \mathrm{~km}^{3}$ of the glacier. Iceberg decrease has transformed the water stream. As a result, during the last three decades, the average yearly water flow has declined by $3.3 \mathrm{~km}^{3}$ in Tajikistan (Alamanov et al., 2006).

The other primary factor which documented well in literature is the extremely irrationality of water use and archaic irrigation ("World Bank," 2004) which contributed to the most catastrophic CC event the disappearance of Aral Sea. According to studies of the reasons for Aral Sea disappearance, the only one-fifth is defined by physical stream deficiency, and $80 \%$ undisputedly associated to the inefficient treatment of water for agriculture demands).

The Metz (2007) $3^{\text {rd }}$ statement presents a comprehensive examination of difficulties of the rainfall modeling and forecasting. Notwithstanding inconsistencies in the estimates for various models, it was feasible to make the aggregate prediction of variations in yearly runoff based on 12 models.

Uzbekistan is facing growing problems to satisfy future demand for water. By the 2040s, even with an increase in the flow of river basins of Amu-Darya and Syr-Darya, a general shortage of water for irrigation in Uzbekistan, according to estimates, could reach $8.0 \%$, at constant drain $-15.4 \%$, while reducing the flow of water deficit could reach $33.5 \%$. Within short time due to increase in temperature on a global level, the water supplies of the big rivers in Kazakhstan may reduce by $20-40 \%$.

Water in CA represents an extremely political subject due to its uneven allocation between upstream and downstream nations and can cause water conflicts (Glantz, 2005). Thus, the water challenges and political stability cannot be addressed independently (Bernauer \& Siefgried, 2012). The study on water shortage factors in CA reveals that the existing obsolete irrigation system remains the primary cause of water loss and soil degradation. Further, insufficient funds mainly resulting from low collection rate do not allow modernization of the water supply systems and increases the maintenance costs. And finally, the lack skilled specialists, especially in the remote areas lead to inefficient water management.

The importance of irrigated agriculture in the region requires modernization of the irrigation system and enhance the effectiveness of water consumption. The farming practice should be adapted to combine new crops that are more proper to new weather circumstances and diverse soil structure and precipitation. One consequence of a declining agricultural area is the growing challenge of securing maintenance in the countryside, encouraging migration to city centers.

\section{Conclusion}

CA faces notable signals from weather change, with some severe risks already in evidence. The results of the study show that there is an increase of shortage of water resources and decline of water condition, the likelihood of appearance of critical and extreme climate events, such as dehydration, extremely high or low temperatures. Moreover, the results indicate that the chance of appearance of social disorder and pressure connected with $\mathrm{CC}$ and adverse effects on the current environment and a warning to biodiversity continues to increase. Being essential for food security and stable household income in $\mathrm{CA}$, the water and agriculture, at the same time are the two of the most vulnerable sectors to $\mathrm{CC}$. 
The results of the surveyed Osh oblast shows that sales of primary agriculture products are the second largest household income (20\% of cash earnings) after remittances from abroad. The results of the assessment conducted by the National County Assessments show that agriculture contributes about one-third of GDP in CA and supplies jobs for more than $60 \%$ of the people. However, unfavorable weather and climate conditions cause $70 \%$ potential damage on agriculture in the CA. According to Metz (2007) forecast, in western and southern areas of CA, where the farming facilities established, and the diverse population lives, one may assume yearly runoff to reduce by $10-20 \%$. For instance, Uzbekistan is facing increasing problems to satisfy future demand for water, and by the 2040 s, the water deficit could reach $33.5 \%$.

As such, a better perception of the environment change impacts in CA requires to support the national governments to interact with other sub-national and local decision-makers, mobilize political will, assess options and design cost-effective and timely responses. In the face of general geographical vulnerabilities, nations in CA should collaborate in improving responses to weather impacts. To this end, mitigation and adaptation interventions need to be precisely planned not to aggravate or exacerbate tensions in the region. Finally, it is a means to advance understanding of the dangers of $\mathrm{CC}$ in the regional scope and enables action across scales to address CC.

\section{References}

Alamanov, S., Pelevkin, V., Podrezov, O., \& Podrerzov, A. (2006). Climate change and water problems in Central Asia [Scholarly project]. Educational course for natural sciences and humanities students, Moscow, WWF, UNEP

Anisimov, O. A., \& Ginsburg, A. S. (2008, July 01). Russian and Neighboring Countries: Environmental, economic and social impacts of climate change | Oxfam GB. Retrieved April 01, 2017, from

http://www.policy-practice.oxfam.org.uk/publications/russian-and-neighbouring-countries-environmental-economic-andsocial-impacts-of-112519

Bell, M. L., Goldberg, R., Hogrefe, C., Kinney, P. L., Knowlton, K., Lynn, B., Patz, J. A. (2007). Climate change, ambient ozone, and health in 50 US cities. Climatic Change,82(1-2), 61-76. doi:10.1007/s10584-006-9166-7

Bernard, L., Semmler, W., \& Sachs, J. D. (2015). Climate Change and Intergenerational Well-Being. The Oxford Handbook of the Macroeconomics of Global Warming. doi:10.1093/oxfordhb/9780199856978.013.0011;

Bernauer, T., \& Siegfried, T. (2012). Climate change and international water conflict in Central Asia. Journal of Peace Research,49(1), 227-239. doi:10.1177/0022343311425843.

Bezborodov, G., Shadmanov, D., Mirhashimov, R., Yuldashev, T., Qureshi, A., Noble, A., \& Qadir, M. (2010). Mulching and water quality effects of soil salinity and sodicity dynamics and cotton productivity in Central Asia. Agriculture, Ecosystems \& Environment, 138(1-2), 95-102. doi:10.1016/j.agee.2010.04.005.).

Bobojonov, I., \& Aw-Hassan, A. (2014). Impacts of climate change on farm income security in Central Asia: An integrated modeling approach. Agriculture, Ecosystems \& Environment,188, 245-255. doi:10.1016/j.agee.2014.02.033

Bucknall, L., Klytchnikova, I., Lampietti, J., Lundell, M., Scatasta, M., \& Thurman, M. (2003). Irrigation in Central Asia. Social, Economic and Environment Considerations. World Bank. Retrieved January 15, 2017, from

http://siteresources.worldbank.org/ECAEXT/Resources/publications/Irrigation-in-Central-Asia/Irrigation_in_Central_AsiaFull_Document-English.pdf

Dessai, S. (2003). Heat stress and mortality in Lisbon Part II. An assessment of the potential impacts of climate change. International Journal of Biometeorology,48(1), 37-44. doi:10.1007/s00484-003-0180-4.

Dukhovny, V., \& Sokolov, V. (2003). Lessons on cooperation building to manage water conflicts in the Aral Sea Basin. (Rep.). Paris: UNESCO-IHP.

Fay, M., Block, R. I., \& Ebinger, J. O. (2010). Adapting to climate change in Eastern Europe and Central Asia. Washington, DC: World Bank.

FAO. (2014). Rural Women in Eastern Europe and Central Asia - FAO. Retrieved Jan. \& Feb., 2017, from http://www.bing.com/cr?IG=534615291A7F48CABC9ED32A5E0E00EA\&CID=18D00DE773A761F808CA077272A160D

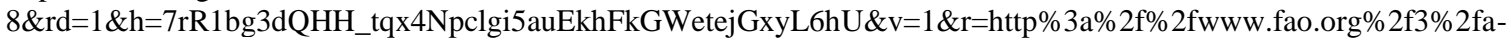
i3840e.pdf\&p=DevEx,5061.1

Flaherty, M., Gevorkyan, A., Radpour, S., \& Semmler, W. (2016). Financing climate policies through climate bonds - A three stage model and empirics. Research in International Business and Finance. doi:10.1016/j.ribaf.2016.06.001;

Glantz, M. H. (2005). Water, Climate, and Development Issues in the Amu Darya Basin. Mitigation and Adaptation Strategies for Global Change, 10(1), 23-50. doi:10.1007/s11027-005-7829-8.

Granit, J., Jägerskog, A., Löfgren, R., Bullock, A., Gooijer, G., Pettigrew, S., \& Lindström, A. (2010). Regional Water Intelligence Report Central Asia - Baseline Report, Regional Water Intelligence Reports (Rep. No. 15). Stockholm: UNDP, Water Governance Facility (WGF).

Lecocq, F., \& Shalizi, Z. (2007). How Might Climate Change Affect Economic Growth In Developing Countries? A Review Of The Growth Literature With A Climate Lens. Policy Research Working Papers. doi:10.1596/1813-9450-4315; 
Mackay, A. (2008). Climate Change 2007: Impacts, Adaptation, and Vulnerability. The contribution of Working Group II to the Fourth Assessment Report of the Intergovernmental Panel on Climate Change. Journal of Environment Quality,37(6), 2407. doi:10.2134/jeq2008.0015.

Metz, B. (2007). Climate change 2007: mitigation of climate change: contribution of Working Group III to the Fourth Assessment Report of the Intergovernmental Panel on Climate Change. Cambridge: Cambridge Univ. Press.

Ndamani, F., \& Watanabe, T. (2017). Determinants of Farmers' Climate Risk Perceptions in Agriculture-A Rural Ghana Perspective. Water,9(3), 210. doi:10.3390/w9030210

Savoskul, O. S., Shevnina, E. V., Perziger, F., Barburin, V., \& Danshin, A. (n.d.). How much water will be available for irrigation in the future? The Syr Darya Basin (Central Asia). Climate change in contrasting river basins: adaptation strategies for water, food and environment, 93-113. doi:10.1079/9780851998350.0093.

Siegfried, T., Bernauer, T., Guiennet, R., Sellars, S., Robertson, W., Mankin, J., Yakovlev, A. (2011). Will climate change exacerbate water stress in Central Asia? Climatic Change,112(3-4), 881-899. doi:10.1007/s10584-011-0253-z

Solomon, S. (2007). Climate change 2007: the physical science basis; contribution of Working Group I to the Fourth Assessment Report of the Intergovernmental Panel on Climate Change: summary for policymakers. Cambridge: Cambridge University Press.

Sommer, R., Glazirina, M., \& Yuldashev, T. (2012). Impact of Climate Change on Rural Livelihood in Central Asia Component 1: "Assessing the Vulnerability of Selected Agro-Ecosystems in Central Asia to Threats Resulting from Climate Change - Production and Productivity of Wheat. [Scholarly project]. Adaptation to Climate Change in CA and China.

Stern, N., (2007). The Economics of Climate Change. doi:10.1017/cbo9780511817434.

Tirado, M., Clarke, R., Jaykus, L., Mcquatters-Gollop, A., \& Frank, J. (2010). Climate change and food safety: A review. Food Research International, 43(7), 1745-1765. doi:10.1016/j.foodres.2010.07.003.

World Bank report on water and power resources in Central Asia (Working paper No. 4315). (2004). Washington: WB 